\title{
Glycosylation of thyroid-stimulating hormone receptor
}

\author{
Paulina Korta, Ewa Pocheć \\ Department of Glycoconjugate Biochemistry, Institute of Zoology and Biomedical Research, Jagiellonian University, Krakow, Poland
}

\begin{abstract}
Thyroid-stimulating hormone receptor (TSHR) is a typical membrane receptor with 7-transmembrane helix domain (7TMR), coupled to the $\mathrm{G}$ protein. The mature receptor, present in the cell membrane, is composed of the A subunit comprising a large extracellular domain, and the B subunit, which consists of a short extracellular fragment anchored in the cell membrane and an intracellular part. The TSH receptor is subject to numerous post-translational modifications that determine its final structure and significantly affect its activity. One of them is glycosylation. TSHR is abundantly $\mathrm{N}$-glycosylated, due to the presence of six $\mathrm{N}$-glycosylation sites in the extracellular domain (Asn77, Asn99, Asn113, Asn177, Asn198, Asn302), mostly evolutionarily conserved. N-glycans constitute 30-40\% of the receptor molecular weight. The glycans are necessary for the receptor trafficking to the plasma membrane and binding of TSH to the receptor. Fucosylated and sialylated $\mathrm{N}$-oligosaccharides were found on TSHR molecules. The increased sialylation of TSHR glycans correlates positively with the receptor binding ability and prolongs the time of receptor incorporation into the cell membrane. TSHR is the main autoantigen in Graves' disease (GD), one of the thyroid autoimmune diseases. One hypothesis assumes that the higher N-glycosylation of THSR in human compared to animals influences the breaking of autotolerance and GD development. $N$-oligosaccharides are the important part of THSR molecule, necessary for the proper functioning of receptors and probably involved in thyroid autoimmunity in GD. (Endokrynol Pol 2019; 70 (1): 86-93)
\end{abstract}

Key words: TSHR; N-glycosylation; sialylation; thyroid; Graves' disease

\section{Introduction}

The attachment of oligosaccharides (glycans) to proteins, named glycosylation, is the most widespread and diverse complex posttranslational modification. The addition of carbohydrates to polypeptide chains results in an extensive heterogeneity of glycosylated proteins. Glycans change significantly the physicochemical properties of proteins [1]. Furthermore, glycosylation plays an important role in many biological processes, mainly in correct folding of proteins, cell-cell interactions, plasma membrane organisation, and immune response. Glycosylated proteins (glycoproteins) are present in every tissue and cell of our body. It is estimated that more than half of all proteins contain bound oligosaccharides [2-4]. Thyroid-stimulating hormone receptor (TSHR) is one of the highly glycosylated membrane proteins. $N$-oligosaccharides constitute over $30 \%$ of this glycoprotein's molecular weight. The glycan part is essential to TSHR function [5]. In this review, we characterise the structure of glycans identified in TSHR and their role in receptor biology.

\section{N-glycosylation}

$\mathrm{N}$-glycosylation is, alongside $\mathrm{O}$-glycosylation and $\mathrm{O}$-GlcNAcylation, one of the most common types of protein glycosylation. In this process glycans are covalently attached to the amide nitrogens of asparagine side chains in the Asn-X-Ser/Thr sequence (where $X$ is any amino acid except proline) via $N$-acetylglucosamine (GlcNAc) residue. There are many potential glycosylation sites in the polypeptide molecule, but this process does not occur at any such site. A variety of enzymes are involved in the $\mathrm{N}$-glycosylation process, classified into two groups: glycosyltransferases responsible for the attachment of new sugar residues and glycosidases that remove monosaccharides by hydrolysis of glycosidic linkages. All $\mathrm{N}$-oligosaccharides have the same pentasaccharide core built of two GlcNAc and three mannoses $\left(\mathrm{GlcNAc}_{2} \mathrm{Man}_{3}\right)[6,7]$.

Depending on the composition of the side chains, three main classes of $\mathrm{N}$-glycan structures are distinguished: high-mannose/oligomannose, complex, and hybrid type. The high-mannose glycans are the oldest evolutionary units, which in the outer part contain between five and nine Man residues. The complex-type oligosaccharides, in contrast to high-mannose structures, are built in the outer part with GlcNAc and galactose (Gal) but not Man residues. They are often terminated with fucose (Fuc) and sialic acid (SA). The hybrid-type oligosaccharides are intermediate forms between high-mannose and complex-type structures because they contain both the mannose chain and the 


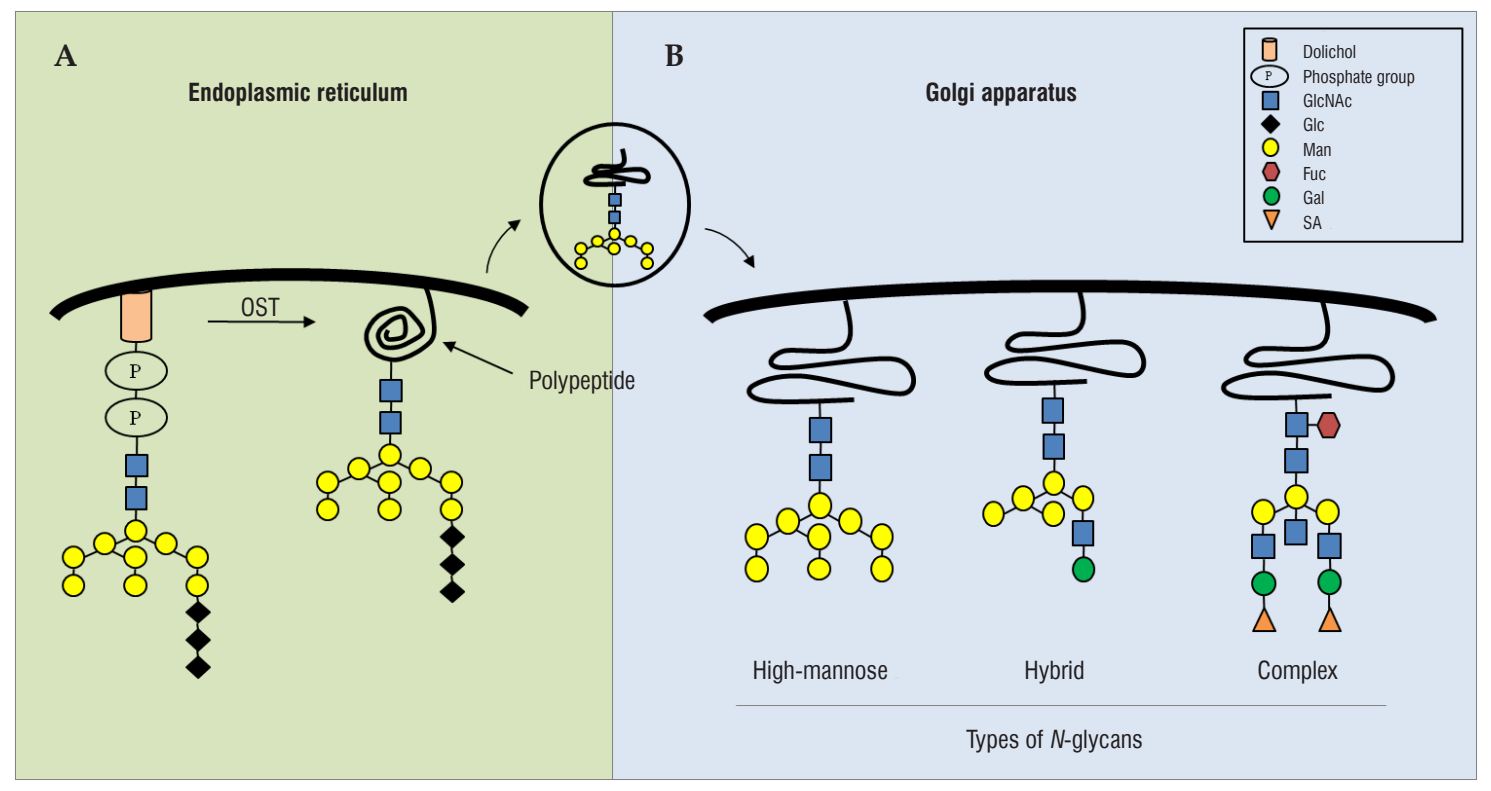

Figure 1. Simplified scheme of the N-oligosaccharide synthesis. A. The tetradecasaccharide precursor $\left(G c_{3} M_{a n} G l c N A c_{2}\right)$ is attached to the phosphorylated dolichol, and in the endoplasmic reticulum it is transferred en bloc to the nascent protein by the oligosaccharyltransferase (OST). B. After transfer to the Golgi apparatus, the main types of $N$-glycans are formed as the result of N-oligosaccharide processing: high-mannose, hybrid-type, and complex-type structures. Fuc - fucose; Gal - galactose; Glc - glucose; GlcNAc - N-acetylglucosamine; Man - mannose; SA - sialic acid

complex-type antenna. Synthesis of oligosaccharides and their attachment to proteins takes place within the endoplasmic reticulum (ER) and Golgi apparatus (Fig. 1) [8-10].

The degree of protein $\mathrm{N}$-glycosylation depends on the activity of enzymes and the availability of precursors, nucleotide sugars. Most of them are formed in the cytoplasm from nucleotides, such as uridine diphosphate (UDP) or guanosine diphosphate (GDP) [11]. Biosynthesis of $\mathrm{N}$-glycans consists of four stages: synthesis of the lipid-linked oligosaccharide precursor, transfer of the sugar chain to the protein, processing, and elongation of $\mathrm{N}$-oligosaccharides. The precursor of all $\mathrm{N}$-glycan structures, formed inside the ER, is a tetradecasaccharide $\left(\mathrm{Glc}_{3} \mathrm{Man}_{9} \mathrm{GlcNAc}_{2}\right)$ attached to dolichol. This $\mathrm{N}$-glycan precursor is then transferred en bloc from dolichol to Asn residue in the nascent polypeptide by enzyme oligosaccharyltransferase (OST) (Fig. 1A). After transferring to protein all three glucoses (Glc) are removed by glucosidases, resulting in the formation of high-mannose structure $\left(\mathrm{Man}_{9} \mathrm{GlcNAc}_{2}\right)$ $[12,13]$. At this stage, two endogenous lectins assist in the formation of the spatial structure of protein: calnexin (CNX) and calreticulin (CRT). They act as the molecular chaperons and have the ability to bind to the nascent protein by Glc residue in the $\mathrm{Glc}_{1} \mathrm{Man}_{9} \mathrm{GlcNAc}_{2}$ glycan attached to this protein. The presence of such a structure on the polypeptide indicates its incomplete or incorrect conformation. The association of CNX/CRT with Glc results in decreased glycoprotein aggregation and increased folding efficiency. The trimming of the terminal Glc in the precursor oligosaccharide is a signal to release protein with the correct conformation from the ER [14-16]. After completion of the synthesis, the $\mathrm{N}$-glycosylated protein is transported to Golgi apparatus where $\mathrm{N}$-oligosaccharides may undergo further modifications. The enzymes located in the Golgi cisternae rebuild the high-mannose structures until the final forms of $N$-glycan are formed (Fig. 1B). The different expression of glycoenzymes dependent on the cell type plays the most important role in determining the degree and type of protein glycosylation and results in the formation of diverse glycoforms (protein glycosylation variants) $[17,18]$.

\section{Thyroid-stimulating hormone receptor (TSHR)}

Thyroid-stimulating hormone receptor (TSHR) is a member of the glycoprotein hormone receptor (GPHR) subfamily that belongs to the leucine-rich repeat-containing GPCR family (LGR), which includes also follicle-stimulating hormone (FSH), luteinising hormone (LH), and human chorionic gonadotropin (hCG) receptors $[19,20]$. The TSHR gene is located on chromosome 14q31.1 and spans 190778 bp, which contains 10 exons [21]. Based on the cDNA sequence, the length of TSHR was estimated on 764 amino acids. TSHR has the predicted molecular weight of $84.5 \mathrm{kDa}$ [22]. In addition to thyroid cells, expression 
of TSHR is detected, among others, in lymphocytes, adipose tissue, and brain [23].

\section{The structure of TSHR}

TSHR is a classical G protein-coupled receptor built of seven transmembrane hydrophobic domains. The Nterminus of the receptor is directed on the outside of the cell. The extracellular domain (ectodomain) accounts for one-half the molecular weight of TSHR and contains the TSH binding site, which has the nine motifs rich in leucine (leucine-rich regions, LRR). The carboxyl-end is located on the cytoplasmic side and is responsible for the interaction with $G$ proteins [24, 25]. In contrast to other members of LGR, TSHR undergoes several posttranslational modifications and it may explain why it is engaged in autoimmunity [22]. A proteolytic cleavage is the first TSHR modification occurring in the ectodomain and leading to the formation of the large A and smaller B subunits. The A and B subunits are interconnected by the disulphide bonds. Two basic proteolytic sites have been determined; the first $\mathrm{N}$-terminal site is located between 304 and 316 amino acids, and the second C-terminal is placed within the 366-369 amino acid sequence. The B subunit consists of the transmembrane domain passing seven times through the cell membrane, an intracellular part, and a carboxylic fragment. The A subunit is the major part of the ectodomain. A peptide C links A and B subunits (Fig. 2). The proteolytic cleavage is catalysed by metalloproteases or the enzymes similar to tumour necrosis factor convertase $[26,27]$. It has been suggested that the enzymes responsible for the proteolytic cleavage may belong to the ADAM family. The ADAMs (a disintegrin and metalloproteinases) are the membrane-associated proteins that play a role in various processes including cytokine and growth factor shedding, cell-cell interactions, and fusion of cells membranes. Both the cleaved and uncleaved forms of TSHR are present on the cells surfaces, but in different proportions. The predominance of one of these forms may be regulated by TSH, cell-cell interactions, or receptor multimerisation $[28,29]$.

\section{The role of TSHR}

TSHR plays a critical role in the development and the proper functioning of thyroid gland. One thyrocyte (thyroid follicular cell) contains about 1000 TSHR molecules on its surface. Binding of the TSH molecule to its receptor leads to a change of the TSHR conformation [30]. This results in phosphorylation of GDP to GTP (guanosine triphosphate) in the G protein subunit and its activation. Then the $G$ protein dissociates into the active $\mathrm{G} \alpha$-GTP subunit and the inactive G $\beta \gamma$. G $\alpha$-GTP subunit activates adenylyl cyclase or phospholipase $C$ (PLC). Adenylyl cyclase activates protein kinase A (PKA) via cyclic $3^{\prime}, 5^{\prime}$-adenosine monophosphate (cAMP), whereas PLC breaks down phosphatidylinositol (IP) to diacylglycerol (DAG) and inositol trisphosphate $\left(\mathrm{IP}_{3}\right)$. DAG activates protein kinase $\mathrm{C}$, and $\mathrm{IP}_{3}$ releases $\mathrm{Ca}^{2+}$ ions from the ER $[31,32]$. Protein kinases activate

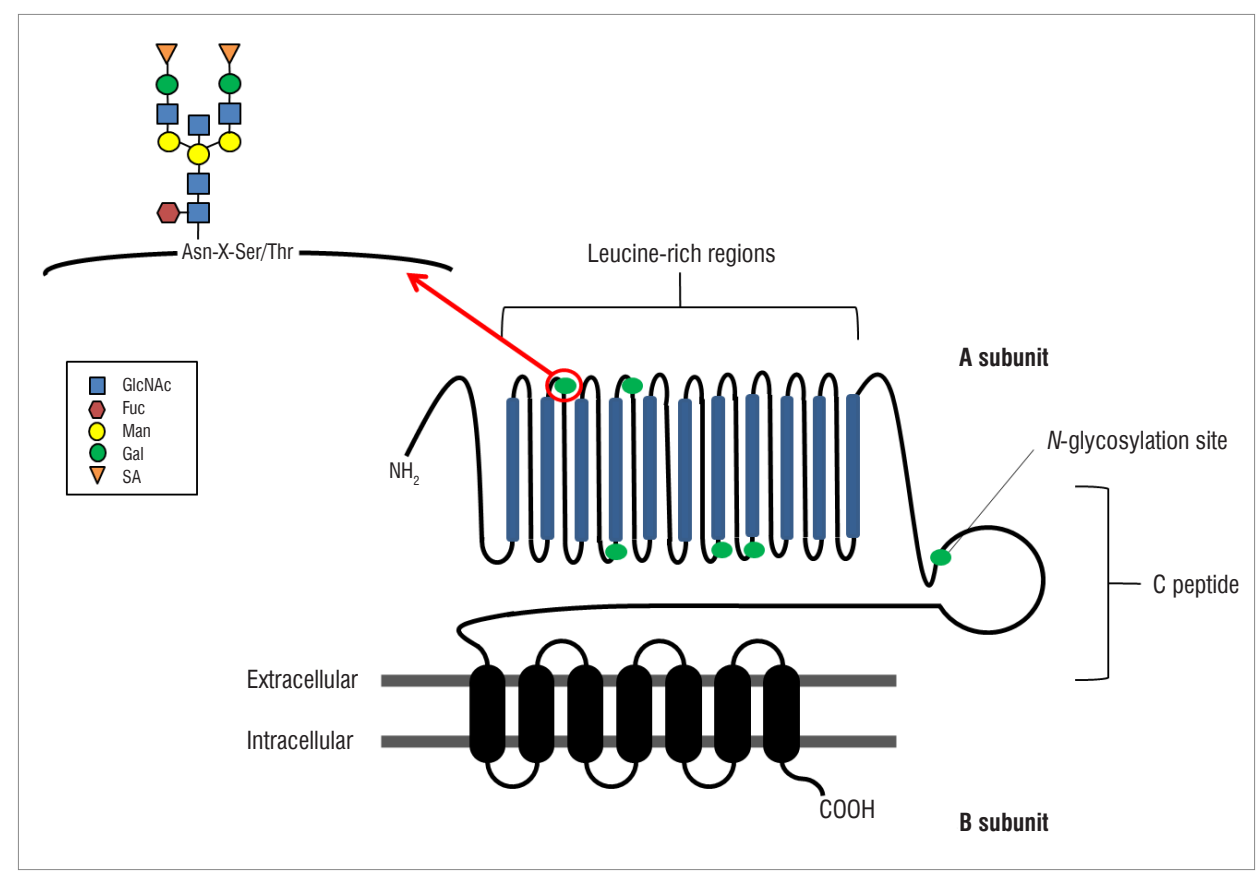

Figure 2. Structure of TSHR with marked potential N-glycosylation sites. Asn — asparagine; Fuc — fucose; Gal — galactose; GlcNAc — N-acetylglucosamine; Man — mannose; SA — sialic acid; Ser — serine; Thr — threonine; X — any amino acid except proline 
further signalling mechanisms that ultimately stimulate many processes involved in the synthesis and release of thyroid hormones, mainly iodine uptake, hydrogen peroxide production, and increased thyroperoxidase (TPO) synthesis [33, 34]. The binding of TSH to its receptor stimulates the production and release of thyroid hormones: triiodothyronine $\left(\mathrm{T}_{3}\right)$ and thyroxine $\left(\mathrm{T}_{4}\right)$. Thyroid hormones play pleiotropic roles, and among them the control of metabolism by increased production of energy is the most important task of thyroid gland endocrine regulation. $\mathrm{T}_{3}$ and $\mathrm{T}_{4}$ activate oxidative enzymes and enzymes of the respiratory chain, as well as increasing the number and size of mitochondria [24].

TSHR may induce different effects depending on the tissue where it is expressed. In rodent pancreatic islets binding of TSH to its receptor stimulates the activity of glucose transporter 2 (GLUT2) promoter [35]. The lack of TSHR expression in the liver disrupts hepatic lipid metabolism. Mice with liver-specific TSHR-knockout have lower levels of cholesterol carried by low-density lipoproteins (LDLs) in the liver and serum [36]. Activation of TSHR is involved in the mesenchymal stem cell differentiation into white and brown adipose tissue [37]. The recent studies performed by Liu et al. showed that TSHR also is involved in the development of thyroid cancers. Their results showed that a lack of TSHR contributes to the formation of distant metastasis in patients with differentiated thyroid cancers (DTC), which results in a poor survival rate. The expression of TSHR down-regulates cancer cell invasion by inhibiting the epithelial-mesenchymal transition (EMT) of differentiated thyroid cancer cells [38].

TSHR is the main autoantigen in Graves' disease (GD), one of the most common autoimmune thyroid diseases (AITDs). The reason for the development of AITD is the breakdown of immunological tolerance to TSHR and the increased thyroid activity. The loss of self-tolerance results in the production of autoantibodies against TSHR (TRAbs) [39]. Depending on the effect of the autoantibody on thyroid activity, two types of TRAbs are distinguished. One of them acts like an agonist of TSH and stimulates the TSHR activity increasing thyroid hormone synthesis, which leads to hyperthyroidism. These stimulating TRAbs are present in the majority of GD patients. The second TRAbs, named blocking antibodies, occur less often and inhibit receptor activation [40]. Importantly, the main autoantigen that binds to stimulating TRAb is not TSH receptor but its shed A subunit. Although GD is a common AITD and affects approximately $1 \%$ of the population, the determination of the TRAb level in patient serum is difficult using conventional diagnostic methods, like enzyme-linked immunosorbent assay (ELISA) or Western blotting. The measurement of inhibition of
TSH binding to TSHR is one of the methods of TRAb detection [41].

The immune response against TSHR can also lead to the development of a thyroid-associated orbitopathy (TAO). Ophthalmopathy is most often the result of autoimmune reactions that take place in the spaces outside the eyeballs. In these places macrophages, T and B cells are concentrated, and collagen and glycosaminoglycans are excessively deposited, which results in water accumulation. It causes swelling and enlargement of the oculomotor muscles. TAO is a common symptom of GD and is called Graves' ophthalmopathy. Both TSHR and TRAb are probably the triggering factors of the inflammatory process within the eye sockets $[42,43]$.

The exact reasons for thyroid autoimmunity development have not been fully understood; however, it was confirmed that both genetic and environmental factors affect autoimmune processes in thyroid gland [44]. Janegova et al. showed that Epstein-Barr virus (EBV) infection plays a potential role in the development of AITD. They examined 34 patients with AITD for the presence of EBV in thyroid cells. The expression of viral RNA was observed in $62.5 \%$ of samples of GD. The presence of EBV was observed mainly in the nucleus of thyroid follicular cells [45]. It was demonstrated that the soluble A subunit of TSHR present in the bloodstream may play a role in initiation of immune response. The release of the A subunit is mainly the result of a disruption of disulphide bridges between $A$ and $B$ subunits by protein disulphide isomerase. Molecular mimicry can also contribute to the development of GD. A presence of microbial and viral pathogens with structure similar to human TSHR leads to the production of autoantibodies directed also against this receptor and the disruption of self-tolerance [23].

\section{TSHR glycosylation}

Glycosylation is a one of the posttranslational modifications of TSHR. N-oligosaccharides attached to TSHR mainly in the ectodomain region (Fig. 2) constitute almost one third of this glycoprotein $[5,46]$. The early study of the TSHR-linked oligosaccharides showed that the mature, fully-glycosylated form of the human recombinant receptor expressed in Chinese hamster ovary cell line (CHO-K1) contains structures with bisecting GlcNAc $\beta(1,4)$-linked to the trimannosyl core of $N$-glycans, core Fuc $\alpha(1,6)$-linked to the innermost GlcNAc, Fuc $\alpha(1,3)$-linked to N-acetyllactosamine (LacNAc) on antenna, and $\alpha(1,3)$-linked Man. This study proved also that the fully glycosylated thyrotropin receptor is $\alpha(2,3)$-sialylated because it reacts with Maackia amurensis lectin 2 (MALII). Besides the mature TSHR with molecular mass of $120 \mathrm{kDa}$, the lower band was detectable in Western blotting of CHO-K1 lysates. The 
$100 \mathrm{kDa}$ band corresponded to the TSHR precursor containing the oligomannose $N$-glycans recognised by Concanavalin A lectin (Con A) specific for $\alpha$-linked Man and by Galanthus nivalis lectin (GNL) preferentially binding $\alpha(1,3)$-linked Man residues [47]. During processing in Golgi apparatus high-mannose $N$-glycans are converted into the complex-type oligosaccharides, which are characteristic for the mature receptor present in cell membrane. The complex-type $N$-glycans are necessary for the transport of TSHR to cell membrane [48]. De-N-glycosylated TSHR was not expressed on the thyroid cell surface. Furthermore, the presence of sialylated structures on TSHR protects the protein against proteolysis [49].

An increased content of SA in TSHR glycans correlates positively with binding of TSH to its receptor and extends the time of the receptor insertion into the plasma membrane. Depending on the type of sialyltransferase (SIAT) that attached SA to glycans in terminal positions, the differences in the TSHR expression on the cell surface was shown. The co-transfection of SIAT1 and SIAT8a with TSHR considerably increased receptor cell-surface expression in COS-7 African green monkey kidney fibroblast-like cell line in comparison to SIAT4a transfection. What is more, the co-transfection of SIAT1 and SIAT8a increased the accumulation of cAMP and production of $\mathrm{IP}_{3}[50]$.

TSHR contains six potential $N$-glycosylation sites in the outer domain at Asn77, Asn99, Asn113, Asn177, Asn198, and Asn302 (Fig. 2). Most of them are evolutionarily conservative, only Asn113 is a unique trait of the human TSHR [51]. The previous study showed that the replacing Asn with glutamine at positions 77 or 113 using the site-directed mutagenesis affects the biological activity of TSHR. The lack of $N$-glycans attached to Asn77 and Asn113 caused the total loss of TSH-stimulated cAMP synthesis. De-N-glycosylation of other sites had no effect on TSHR activity. Moreover, the mutation at Asn77 completely removed the receptor affinity for TSH, as in the case of the absence of all six $N$-glycans. The mutation of Asn113 only decreased this affinity [52]. Therefore, it can be concluded that the presence of $\mathrm{N}$-glycans is indirectly needed for the attachment of TSH and may affect the binding of TRAbs in GD. The results of reports on insects (Spodoptera frugiperda) and bacteria (Escherichia coli) cells that produced non-glycosylated or partially glycosylated TSHRs supported this conclusion because TSHRs expressed in both these organisms were unable to bind TRAbs and thyrotropin or bound it with low affinity [53-55]. The addition of $\mathrm{N}$-oligosaccharides to four of six $N$-glycosylation sites on TSHR is necessary to bind the appropriate amount of CNX/CRT lectin chaperones required for proper receptor folding in the ER. TSHR mutants glycosylated at three or fewer sites may not achieve the correct conformation and are not transported to cell membrane but remain trapped in ER [51].

Siffroi-Fernandez et al. showed that the interactions between CNX/CRT and glycosylated TSHR slow down receptor degradation and have a positive effect on TSHR stabilisation [56]. One hypothesis assumes that the presence of six $N$-glycans on the surface of human TSHR is one of the factors influencing GD development. There are only four sites of $N$-glycosylation in fish TSHR, and GD has never been observed in cats, dogs, and mice with five $\mathrm{N}$-glycosylation sites; therefore, it is possible that the higher TSHR $N$-glycosylation may correlate with the degree of receptor immunogenicity and have an affect on the breakdown of immunological tolerance $[57,58]$.

In the first stage of an autoimmunity process in AITD, thyroid antigens are captured, internalised, and processed by antigen-presenting cells (APCs) such as macrophages and dendritic cells. APCs present specific thyroid antigens to T and B cells, and it leads to their activation and the production of autoantibodies [59]. Thyroid surface glycoproteins are recognised by a mannose receptor (ManR) present on the APCs surface. ManRs are calcium-dependent transmembrane proteins with phagocytic and endocytic properties. They contain C-type carbohydrate recognition domains (CRDs), which function as lectins and have the ability to bind Man as well as Fuc, GlcNAc, and sulphate residues in N-glycans [60-62]. In the soluble TSHR A subunit with the molecular weight of $60 \mathrm{kDa}, 43 \%$ of the mass corresponds to $\mathrm{N}$-oligosaccharides. CRDs bind both to TSHR A subunit and TSH holoreceptor via N-glycans. It is believed that this interaction plays an important role in the GD development $[61,63]$. It has been also suggested that A subunit shed from the thyrocyte surface most likely penetrates into thyroid lymph nodes (not into the blood), where is processed by APCs, and it consequently leads to the humoral immune response [29]. $N$-glycans are necessary not only for the recognition of TSHR by APCs, but also are involved in the next step of immune response. Research from the 1990s showed that $\mathrm{N}$-oligosaccharides on TSHR A subunit are involved in the autoantibody binding to receptor [64].

Autoimmune diseases are accompanied by the alterations of antibody (immunoglobulin, Ig) glycosylation. TSHR autoantibodies mainly belong to the G-class of immunoglobulins (IgGs). IgG is composed of Fab fragments that bind an antigen and Fc (crystallisable) fragment responsible for the effector functions. The Fc fragments of IgG contain two N-glycans attached to Asn297. The complete biantennary complex-type IgG structures contain Man, Gal, GlcNAc, and Fuc and may also be $\alpha(2,3)$ - or 
$\alpha(2,6)$-sialylated [10, 41, 65]. The sugar chains of IgG affect its structure by stabilising the conformation and geometry of the molecule and increase resistance to proteases. $\mathrm{N}$-glycans regulate the IgG release by B lymphocytes, their proper functioning, and IgG binding to other proteins. Changes of IgG glycosylation are well documented in some autoimmune diseases, mainly agalactosylation in rheumatoid arthritis [10, 66]. Alteration of glycan structure leads to abnormalities in the binding of IgG to the complement system, which results in uncontrolled complement activation and the development of inflammation [67, 68]. IgG glycosylation has been studied in AITD to a limited extent so far. Glycosylation changes were observed in anti-thyroglobulin (TgAb) IgG in patients with GD and Hashimoto's thyroiditis (HT), another very common AITD. TgAbs are present in the majority of HT (up to $90 \%$ ) and many GD patients (up to $40 \%$ ) [69]. Serum $\mathrm{TgAb}$ showed the lower core fucosylation in HT than GD and thyroid cancers [70], while in comparison to healthy donors the level of $\alpha(1,6)$-fucosylation and sialylation in HT patients was elevated. Moreover, a positive correlation between the amount of sugars attached to IgG and the concentration of $\operatorname{TgAb}$ in the blood of HT patients was observed [71]. Our latest study also showed the altered $\alpha(1,6)$-fucosylation of IgG from AITD patients examined in three huge European cohorts [72]. To date no studies have been performed to determine whether glycosylation of TRAb is changed in GD. The main reason is the low concentration of anti-thyroid $\operatorname{IgG}$, including TRAb, in the human serum of healthy individuals (control group) to purify enough specific thyroid $\mathrm{Ab}$ for comparative profiling of glycan structures by high-throughput methods such as high-performance liquid chromatography (HPLC) [72].

\section{Conclusions}

$\mathrm{N}$-glycosylation is a key process which regulates TSH receptor structure and function [74]. N-glycans are crucial for the proper folding of TSHR protein, the receptor trafficking to the cell membrane, as well as the binding of TSH and TRAb produced in thyroid autoimmunity to TSHR [48]. It is well known that glycosylation plays a significant role in tumour progression, metastasis, and immune modulation of various types of cancers, including thyroid carcinomas $[3,73]$. The contribution of glycosylation changes to disease progress was shown also in autoimmunity processes [66], among others those taking place in the thyroid gland $[72,75]$. It was hypothesised that TSHR glycans are involved in breaking the self-tolerance state in GD [57]. The detailed analysis of TSHR glycosylation alterations in AITD is crucial for verification of this hypothesis and is necessary to better understand the pathological mechanism of thyroid autoimmunity.

\section{References}

1. Arey BJ. The Role of in Receptor Signaling. In: Petrescu S. ed. Glycosylation. InTech, London 2012: 273-286.

2. Kim PJ, Lee DY, Jeong H. Centralized modularity of N-linked glycosylation pathways in mammalian cells. PLoS One. 2009; 4(10): e7317, doi: 10.1371/journal.pone.0007317, indexed in Pubmed: 19802388.

3. Krześlak A, Jóźwiak P, Lipińska A. Glycosylation and glycoproteins in thyroid cancer: a potential role for diagnostics. In: Fahey TJ. ed. Updates in the Understanding and Management of Thyroid Cancer. InTech, London 2012: 90.

4. Varki A. Biological roles of glycans. Glycobiology. 2017; 27(1): 3-49, doi: 10.1093/glycob/cww086, indexed in Pubmed: 27558841.

5. Kursawe R, Paschke R. Modulation of TSHR signaling by posttranslational modifications. Trends Endocrinol Metab. 2007; 18(5): 199-207, doi: 10.1016/j.tem.2007.05.002, indexed in Pubmed: 17524661 .

6. Ohtsubo K, Marth JD. Glycosylation in cellular mechanisms of health and disease. Cell. 2006; 126(5): 855-867, doi: 10.1016/j.cell.2006.08.019, indexed in Pubmed: 16959566

7. Taylor ME, Drickamer K. Introduction to Glycobiology. Oxford University Press, New York 2011.

8. Nettleship JE. Structural Biology of Glycoproteins. In: Petrescu S. ed. Glycosylation. InTech, London 2012: 41-62.

9. Stanley P, Taniguchi N, Aebi M. N-Glycans. In: Varki A, Cummings RD, Esko JD. ed. Essentials of Glycobiology. 3rd ed. Cold Spring Harbor Laboratory Press, Cold Spring Harbor (NY) 2017.

10. Kozłowska K, Rydlewska M, Ząbczyńska M, et al. Glikozylacja IgG w chorobach autoimmunizacyjnych. Postepy Hig Med Dosw. 2018; 72: 975-990, doi: 10.5604/01.3001.0012.7351.

11. Surman M, Janik M. Regulacja procesu glikozylacji białek przez kaskadę cAMP. Post Biochem. 2014; 60: 305-312.

12. Weerapana E, Imperiali B. Asparagine-linked protein glycosylation: from eukaryotic to prokaryotic systems. Glycobiology. 2006; 16(6): 91R-91101R, doi: 10.1093/glycob/cwj099, indexed in Pubmed: 16510493.

13. Moremen KW, Tiemeyer M, Nairn AV. Vertebrate protein glycosylation: diversity, synthesis and function. Nat Rev Mol Cell Biol. 2012; 13(7): 448-462, doi: 10.1038/nrm3383, indexed in Pubmed: 22722607.

14. Caramelo JJ, Parodi AJ. A sweet code for glycoprotein folding. FEBS Lett. 2015; 589(22): 3379-3387, doi: 10.1016/j.febslet.2015.07.021, indexed in Pubmed: 26226420.

15. Harada Y, Hirayama H, Suzuki T. Generation and degradation of free asparagine-linked glycans. Cell Mol Life Sci. 2015; 72(13): 2509-2533, doi: 10.1007/s00018-015-1881-7, indexed in Pubmed: 25772500.

16. Ząbczyńska M, Pocheć E. Rola glikozylacji białek układu odpornościowego. Postepy Bioch. 2015; 61(2): 129-137.

17. Trombetta ES. The contribution of N-glycans and their processing in the endoplasmic reticulum to glycoprotein biosynthesis. Glycobiology. 2003; 13(9): 77R-91R, doi: 10.1093/glycob/cwg075, indexed in Pubmed: 12736198.

18. Schwarz F, Aebi M. Mechanisms and principles of N-linked protein glycosylation. Curr Opin Struct Biol. 2011; 21(5): 576-582, doi: 10.1016/j. sbi.2011.08.005, indexed in Pubmed: 21978957.

19. Davies TF, Ando T, Lin RY, et al. Thyrotropin receptor-associated diseases: from adenomata to Graves disease. J Clin Invest. 2005; 115(8): 1972-1983, doi: 10.1172/JCI26031, indexed in Pubmed: 16075037.

20. Núñez Miguel R, Sanders J, Furmaniak J, et al. Structure and activation of the TSH receptor transmembrane domain. Auto Immun Highlights. 2017; 8(1): 2, doi: 10.1007/s13317-016-0090-1, indexed in Pubmed: 27921237.

21. Iosco C, Rhoden KJ. TSHR (thyroid stimulating hormone receptor). Atlas Genet Cytogenet Oncol Haematol. 2010; 14(9): 846-852, doi: $10.4267 / 2042 / 44845$

22. Rapoport B, Chazenbalk GD, Jaume JC, et al. The thyrotropin (TSH) receptor: interaction with TSH and autoantibodies. Endocr Rev. 1998; 19(6): 673-716, doi: 10.1210/edrv.19.6.0352, indexed in Pubmed: 9861544

23. Chistiakov DA. Thyroid-stimulating hormone receptor and its role in Graves' disease. Mol Genet Metab. 2003; 80(4): 377-388, doi: 10.1016/j. ymgme.2003.09.001, indexed in Pubmed: 14654350.

24. Yen PM. Physiological and molecular basis of thyroid hormone action. Physiol Rev. 2001; 81(3): 1097-1142, doi: 10.1152/physrev.2001.81.3.1097, indexed in Pubmed: 11427693.

25. Szkudlinski MW, Fremont V, Ronin C, et al. Thyroid-stimulating hormone and thyroid-stimulating hormone receptor structure-function relationships. Physiol Rev. 2002; 82(2): 473-502, doi: 10.1152/physrev.00031.2001, indexed in Pubmed: 11917095. 
26. Rapoport B, McLachlan SM. Thyroid Autoantibodies in Graves' Disease. In: Rapoport B, McLachlan SM. ed. Graves' Disease. Endocrine Updates. Vol 6. Springer, Boston 2000.

27. Adler G. Posttranslacyjne modyfikacje receptora tyreotropiny a choroby tarczycy [The posttranslational modification of thyrotropin receptor and thyroid diseases]. Endokrynol Pol. 2005; 56(1): 72-77, indexed in Pubmed: 16335676.

28. Seals DF, Courtneidge SA. The ADAMs family of metalloproteases: multidomain proteins with multiple functions. Genes Dev. 2003; 17(1): 7-30, doi: 10.1101/gad.1039703, indexed in Pubmed: 12514095.

29. Rapoport B, McLachlan SM. TSH Receptor Cleavage Into Subunits and Shedding of the A-Subunit; A Molecular and Clinical Perspective. Endocr Rev. 2016; 37(2): 114-137, doi: 10.1210/er.2015-1098.2016.1.test, indexed in Pubmed: 27454362.

30. Nussey S, Whitehead S. The thyroid gland. In: Endocrinology: an integrated approach. BIOS Scientific Publishers, London 2001.

31. Sorisky A, Gagnon A. Freedom of expression beyond the thyroid: the thyroid-stimulating hormone receptor in the adipocyte. OA Biochemistry. $2014 ; 2(1): 2$.

32. Andrejko M, Mizerska-Kowalska M, Zdzisińska B. Receptory związane z białkami $\mathrm{G}$ w odporności wrodzonej bezkręgowców. Kosmos. 2017; 66(4): 553-562.

33. Davies T, Marians R, Latif R. The TSH receptor reveals itself. J Clin Invest. 2002; 110(2): 161-164, doi: 10.1172/JCI16234, indexed in Pubmed: 12122107.

34. Tuncel M. Thyroid Stimulating Hormone Receptor. Mol Imaging Radionucl Ther. 2017; 26(Suppl 1): 87-91, doi: 10.4274/2017.26.suppl.10, indexed in Pubmed: 28117293.

35. Lyu J, Imachi H, Yoshimoto T, et al. Thyroid stimulating hormone stimulates the expression of glucose transporter 2 via its receptor in pancreatic beta cell line, INS-1 cells. Sci Rep. 2018; 8(1): 1986, doi: 10.1038/s41598-018-20449-3, indexed in Pubmed: 29386586.

36. Zhou L, Wu K, Zhang L, et al. Liver-specific deletion of TSHR inhibits hepatic lipid accumulation in mice. Biochem Biophys Res Commun. 2018; 497(1): 39-45, doi: 10.1016/j.bbrc.2018.01.187, indexed in Pubmed: 29421660.

37. Draman MS, Stechman M, Scott-Coombes D, et al. The Role of Thyrotropin Receptor Activation in Adipogenesis and Modulation of Fat Phenotype. Front Endocrinol (Lausanne). 2017; 8: 83, doi: 10.3389/fendo.2017.00083.

38. Liu T, Men Q, Su X, et al. Downregulated expression of TSHR is associated with distant metastasis in thyroid cancer. Oncol Lett. 2017; 14(6): 7506-7512, doi: 10.3892/ol.2017.7122, indexed in Pubmed: 29344196.

39. Schott M, Scherbaum WA. Autoimmune Thyroid Disease. Dtsch Arztebl. 2006; 103(45): A3023-A3032.

40. Furmaniak J, Sanders J, Rees Smith B. Blocking type TSH receptor antibodies. Auto Immun Highlights. 2013; 4(1): 11-26, doi: 10.1007/s13317-012-0028-1, indexed in Pubmed: 26000138.

41. Ludwig RJ, Vanhoorelbeke K, Leypoldt F, et al. Mechanisms of Autoantibody-Induced Pathology. Front Immunol. 2017; 8: 603, doi: 10.3389/fimmu.2017.00603, indexed in Pubmed: 28620373.

42. Wall JR, Lahooti H. Pathogenesis of thyroid eye disease - does autoimmunity against the TSH receptor explain all cases? Endokrynol Pol. 2010; 61(2): 222-227, indexed in Pubmed: 20464711.

43. Iyer S, Bahn R. Immunopathogenesis of Graves' ophthalmopathy: the role of the TSH receptor. Best Pract Res Clin Endocrinol Metab. 2012; 26(3): 281-289, doi: 10.1016/j.beem.2011.10.003, indexed in Pubmed: 22632365 .

44. Weetman AP. Autoimmune thyroid disease: propagation and progression. Eur J Endocrinol. 2003; 148(1): 1-9, indexed in Pubmed: 12534350.

45. Janegova A, Janega P, Rychly B, et al. The role of Epstein-Barr virus infection in the development of autoimmune thyroid diseases. Endokrynol Pol. 2015; 66(2): 132-136, doi: 10.5603/EP.2015.0020, indexed in Pubmed: 25931043

46. Cho BY. Clinical applications of TSH receptor antibodies in thyroid diseases. J Korean Med Sci. 2002; 17(3): 293-301, doi: 10.3346/jkms.2002.17.3.293, indexed in Pubmed: 12068130

47. Oda Y, Sanders J, Roberts S, et al. Analysis of carbohydrate residues on recombinant human thyrotropin receptor. J Clin Endocrinol Metab. 1999; 84(6): 2119-2125, doi: 10.1210/jcem.84.6.5756, indexed in Pubmed: 10372720 .

48. Nagayama Y, Namba H, Yokoyama N, et al. Role of asparagine-linked oligosaccharides in protein folding, membrane targeting, and thyrotropin and autoantibody binding of the human thyrotropin receptor. J Biol Chem. 1998; 273(50): 33423-33428, doi: 10.1210/en.2004-0437, indexed in Pubmed: 10372720 .

49. Siffroi-Fernandez S, Costagliola S, Paumel S, et al. Role of complex asparagine-linked oligosaccharides in the expression of a functional thyrotropin receptor. Biochem J. 2001; 354(Pt 2): 331-336, doi: doi: 10.1042/bj3540331, indexed in Pubmed: 11171111.

50. Frenzel R, Krohn K, Eszlinger M, et al. Sialylation of human thyrotropin receptor improves and prolongs its cell-surface expression. Mol Phar- macol. 2005; 68(4): 1106-1113, doi: 10.1124/mol.105.012906, indexed in Pubmed: 16014806

51. Nagayama Y, Nishihara E, Namba H, et al. Identification of the sites of asparagine-linked glycosylation on the human thyrotropin receptor and studies on their role in receptor function and expression. J Pharmacol Exp Ther. 2000; 295(1): 404-409, indexed in Pubmed: 10992007.

52. Russo D, Chazenbalk GD, Nagayama Y, et al. Site-directed mutagenesis of the human thyrotropin receptor: role of asparagine-linked oligosaccharides in the expression of a functional receptor. Mol Endocrinol. 1991; 5(1): 29-33, doi: 10.1210/mend-5-1-29, indexed in Pubmed: 2017190.

53. Huang GC, Collison KS, McGregor AM, et al. Expression of a human thyrotrophin receptor fragment in Escherichia coli and its interaction with the hormone and autoantibodies from patients with Graves' disease. J Mol Endocrinol. 1992; 8(2): 137-144, indexed in Pubmed: 1515018

54. Misrahi M, Milgrom E. The TSH Receptor. In: Weetman AP, Grossman A. ed. Pharmacotherapeutics of the Thyroid Gland. Handbook of Experimental Pharmacology. Vol 128. Springer, Berlin 1997.

55. Sanders J, Oda Y, Roberts SA, et al. Understanding the thyrotropin receptor function-structure relationship. Baillieres Clin Endocrinol Metab. 1997; 11(3): 451-479, indexed in Pubmed: 9532334.

56. Siffroi-Fernandez S, Giraud A, Lanet J, et al. Association of the thyrotropin receptor with calnexin, calreticulin and BiP. Efects on the maturation of the receptor. Eur J Biochem. 2002; 269(20): 4930-4937, doi: 10.1046/j.1 432-1033.2002.03192.x, indexed in Pubmed: 12383251.

57. McLachlan SM, Alpi K, Rapoport B. Review and hypothesis: does Graves' disease develop in non-human great apes? Thyroid. 2011; 21(12): 1359-1366, doi: 10.1089/thy.2011.0209, indexed in Pubmed: 22066476.

58. McLachlan SM, Rapoport B. Breaking tolerance to thyroid antigens: changing concepts in thyroid autoimmunity. Endocr Rev. 2014; 35(1): 59-105, doi: 10.1210/er.2013-1055, indexed in Pubmed: 24091783.

59. Mikoś H, Mikoś M, Obara-Moszyńska M, et al. The role of the immune system and cytokines involved in the pathogenesis of autoimmune thyroid disease (AITD). Endokrynol Pol. 2014; 65(2): 150-155, doi: 10.5603/EP.2014.0021, indexed in Pubmed: 24802739.

60. Leteux C, Chai W, Loveless RW, et al. The cysteine-rich domain of the macrophage mannose receptor is a multispecific lectin that recognizes chondroitin sulfates $A$ and $B$ and sulfated oligosaccharides of blood group Lewis(a) and Lewis(x) types in addition to the sulfated N-glycans of lutropin. J Exp Med. 2000; 191(7): 1117-1126, indexed in Pubmed: 10748230.

61. Chazenbalk GD, Pichurin PN, Guo J, et al. Interactions between the mannose receptor and thyroid autoantigens. Clin Exp Immunol. 2005; 139(2): 216-224, doi: 10.1111/j.1365-2249.2004.02689.x, indexed in Pubmed: 15654820.

62. Loke I, Kolarich D, Packer NH, et al. Emerging roles of protein mannosylation in inflammation and infection. Mol Aspects Med. 2016; 51: 31-55, doi: 10.1016/j.mam.2016.04.004, indexed in Pubmed: 27086127.

63. Chen CR, Pichurin P, Nagayama Y, et al. The thyrotropin receptor autoantigen in Graves disease is the culprit as well as the victim. J Clin Invest. 2003; 111(12): 1897-1904, doi: 10.1172/JCI17069, indexed in Pubmed: 12813025

64. Seetharamaiah GS, Dallas JS, Patibandla SA, et al. Requirement of glycosylation of the human thyrotropin receptor ectodomain for its reactivity with autoantibodies in patients' sera. J Immunol. 1997; 158(6): 2798-2804, indexed in Pubmed: 9058815.

65. Goulabchand R, Vincent T, Batteux F, et al. Impact of autoantibody glycosylation in autoimmune diseases. Autoimmun Rev. 2014; 13(7): 742-750, doi: 10.1016/j.autrev.2014.02.005, indexed in Pubmed: 24657512.

66. Maverakis E, Kim K, Shimoda M, et al. Glycans in the immune system and The Altered Glycan Theory of Autoimmunity: a critical review. J Autoimmun. 2015; 57: 1-13, doi: 10.1016/j.jaut.2014.12.002, indexed in Pubmed: 25578468

67. Gińdzieńska-Sieśkiewicz E, Klimiuk PA, Domysławska I, et al. Zaburzenia glikozylacji immunoglobuliny $\mathrm{G}$ w przebiegu reumatoidalnego zapalenia stawów. Postepy Hig Med Dosw. 2005; 59: 485-489, indexed in Pubmed: 16258413.

68. Biermann MHC, Griffante G, Podolska MJ, et al. Sweet but dangerous - the role of immunoglobulin $\mathrm{G}$ glycosylation in autoimmunity and inflammation. Lupus. 2016; 25(8): 934-942, doi: 10.1177/0961203316640368, indexed in Pubmed: 27252272.

69. Franco JS, Amaya-Amaya J, Anaya JM. Thyroid disease and autoimmune diseases. In: Anaya JM, Shoenfeld Y, Rojas-Villarraga A, Levy RA, Cervera R. ed. Autoimmunity: From Bench to Bedside [Internet]. El Rosario University Press, Bogota 2013.

70. Zhao L, Liu M, Gao Y, et al. Glycosylation of sera thyroglobulin antibody in patients with thyroid diseases. Eur J Endocrinol. 2013; 168(4): 585-592, doi: 10.1530/EJE-12-0964, indexed in Pubmed: 23360821.

71. Yuan $\mathrm{S}, \mathrm{Li} \mathrm{O}$, Zhang Y, et al. Changes in anti-thyroglobulin IgG glycosylation patterns in Hashimoto's thyroiditis patients. J Clin Endocrinol Metab. 2015; 100(2): 717-724, doi: 10.1210/jc.2014-2921, indexed in Pubmed: 25380293 
72. Martin T, Simurina M, Zabczynska M, et al. Decreased IgG core fucosylation, a player in antibody-dependent cell-mediated cytotoxicity, is associated with autoimmune thyroid diseases. Biorxiv. 2018, doi: $10.1101 / 362004$

73. Rodrigues JG, Balmaña M, Macedo JA, et al. Glycosylation in cancer: Selected roles in tumour progression, immune modulation and metastasis. Cell Immunol. 2018; 333: 46-57, doi: 10.1016/j.cellimm.2018.03.007, indexed in Pubmed: 29576316
74. Szkudlinski MW, Fremont V, Ronin C, et al. Thyroid-stimulating hormone and thyroid-stimulating hormone receptor structure-function relationships. Physiol Rev. 2002; 82(2): 473-502, doi: 10.1152/physrev.00031.2001, indexed in Pubmed: 11917095

75. Ząbczyńska M, Kozłowska K, Pocheć E. Glycosylation in the Thyroid Gland: Vital Aspects of Glycoprotein Function in Thyrocyte Physiology and Thyroid Disorders. Int J Mol Sci. 2018; 19(9), doi: 10.3390/ijms19092792, indexed in Pubmed: 30227620. 


\title{
Glikozylacja receptora hormonu tyreotropowego
}

\author{
Paulina Korta, Ewa Pocheć \\ Zakład Biochemii Glikokoniugatów, Instytut Zoologii i Badań Biomedycznych, Uniwersytet Jagielloński, Kraków
}

Artykuł jest tłumaczeniem pracy: Paulina Korta, Ewa Pocheć. Glycosylation of thyroid-stimulating hormone receptor.

Endokrynol Pol 2019; 70 (1): 86-93.

Należy cytować wersję pierwotną.

Piśmiennictwo dostępne w wersji pierwotnej na stronach 91-93.

\begin{abstract}
Streszczenie
Hormon tyreotropowy (TSH), produkowany przez gruczołową części przysadki, kontroluje pracę tarczycy przez swoisty receptor (TSHR) zlokalizowany w błonie tyreocytów. Receptor ten jest typowym receptorem błonowym sprzężonym z białkiem G, siedmiokrotnie przechodzącym przez błonę komórkową (7TMR). Dojrzały receptor, obecny w błonie komórkowej, zbudowany jest z podjednostki A obejmującej dużą, zewnątrzkomórkową domenę oraz podjednostki B, na którą składa się krótki zewnątrzkomórkowy fragment zakotwiczony w błonie komórkowej oraz część wewnątrzkomórkowa. Receptor TSH podlega licznym modyfikacjom potranslacyjnym decydującym o jego ostatecznej strukturze oraz w istotny sposób wpływających na jego aktywność. Jest obficie $N$-glikozylowanym białkiem, co wynika z obecności sześciu miejsc N-glikozylacji w domenie zewnątrzkomórkowej (Asn77, Asn99, Asn113, Asn177, Asn198, Asn302), w większości ewolucyjnie konserwatywnych. N-glikany stanowią 30-40\% masy cząsteczkowej receptora. Glikany są niezbędne do transportu receptora do błony komórkowej oraz wiązania TSH przez receptor. W cząsteczkach TSHR stwierdzono obecność $N$-oligosacharydów fukozylowanych i sjalowanych. Zwiększona zawartość kwasów sjalowych w glikanach TSHR pozytywnie koreluje z wiązaniem TSH przez receptor oraz wydłuża czas wbudowania receptora do błony komórkowej. Receptor TSH jest głównym autoantygenem w chorobie Gravesa-Basedowa (GD) będącej chorobą autoimmunizacyjną tarczycy. Jedna z hipotez zakłada, że $N$-glikozylacja TSHR u ludzi wpływa na przełamanie stanu autotolerancji i rozwój GD. $N$-oligosacharydy są niezbędne do prawidłowego funkcjonowania receptora TSH, a także przyczyniają się do patogenezy GD. (Endokrynol Pol 2019; 70 (1): 94-100)
\end{abstract}

Słowa kluczowe: TSHR; N-glikozylacja; sjalilacja; tarczyca; choroba Gravesa-Basedowa

\section{Wstęp}

Dołączanie oligosacharydów (glikanów) do białek, określane jako glikozylacja, jest najbardziej powszechną i zróżnicowaną potranslacyjną modyfikacją. Dodawanie węglowodanów do łańcuchów polipeptydowych skutkuje dużą heterogennością glikozylowanych białek. Glikany znacząco zmieniają właściwości fizykochemiczne cząsteczek [1]. Ponadto, glikozylacja odgrywa ważną rolę w wielu procesach biologicznych, głównie $\mathrm{w}$ prawidłowym fałdowaniu białek, interakcjach między komórkami, organizacji błony komórkowej i odpowiedzi immunologicznej. Glikozylowane białka (glikoproteiny) są obecne w każdej tkance i komórce organizmu. Szacuje się, że więcej niż połowa wszystkich białek zawiera związane oligosacharydy [2-4]. Receptor hormonu tyreotropowego (TSHR, thyroid-stimulating hormone receptor) jest jednym z mocno glikozylowanych białek błonowych. $\mathrm{N}$-oligosacharydy stanowią ponad $30 \%$ masy cząsteczkowej tej glikoproteiny. Do funkcjonowania receptora niezbędna jest część cukrowa
[5]. W niniejszej pracy scharakteryzowano strukturę glikanów zidentyfikowanych w cząsteczce TSHR oraz ich rolę w biologii receptorów.

\section{$N$-glikozylacja}

$N$-glikozylacja jest - obok O-glikozylacji oraz O-GlcNAcylacji - jedną z najbardziej powszechnych modyfikacji potranslacyjnych białek. W procesie $N$-glikozylacji oligosacharydy są kowalencyjnie dołączane do azotu grupy amidowej bocznej reszty asparaginy (Asn) w sekwencji Asn-X-Ser/Thr (gdzie X oznacza dowolny aminokwas oprócz proliny) przez resztę $N$-acetyloglukozoaminy (GlcNAc). W cząsteczce polipeptydu występuje wiele potencjalnych miejsc glikozylacji, ale proces ten nie zachodzi w każdym z nich. Enzymy zaangażowane w proces $\mathrm{N}$-glikozylacji dzieli się na dwie grupy: glikozylotransferazy, odpowiedzialne za dołączanie nowych reszt cukrowych, oraz glikozydazy, które odłączają monosacharydy poprzez hydrolizę wiązań glikozydowych. Wszystkie 


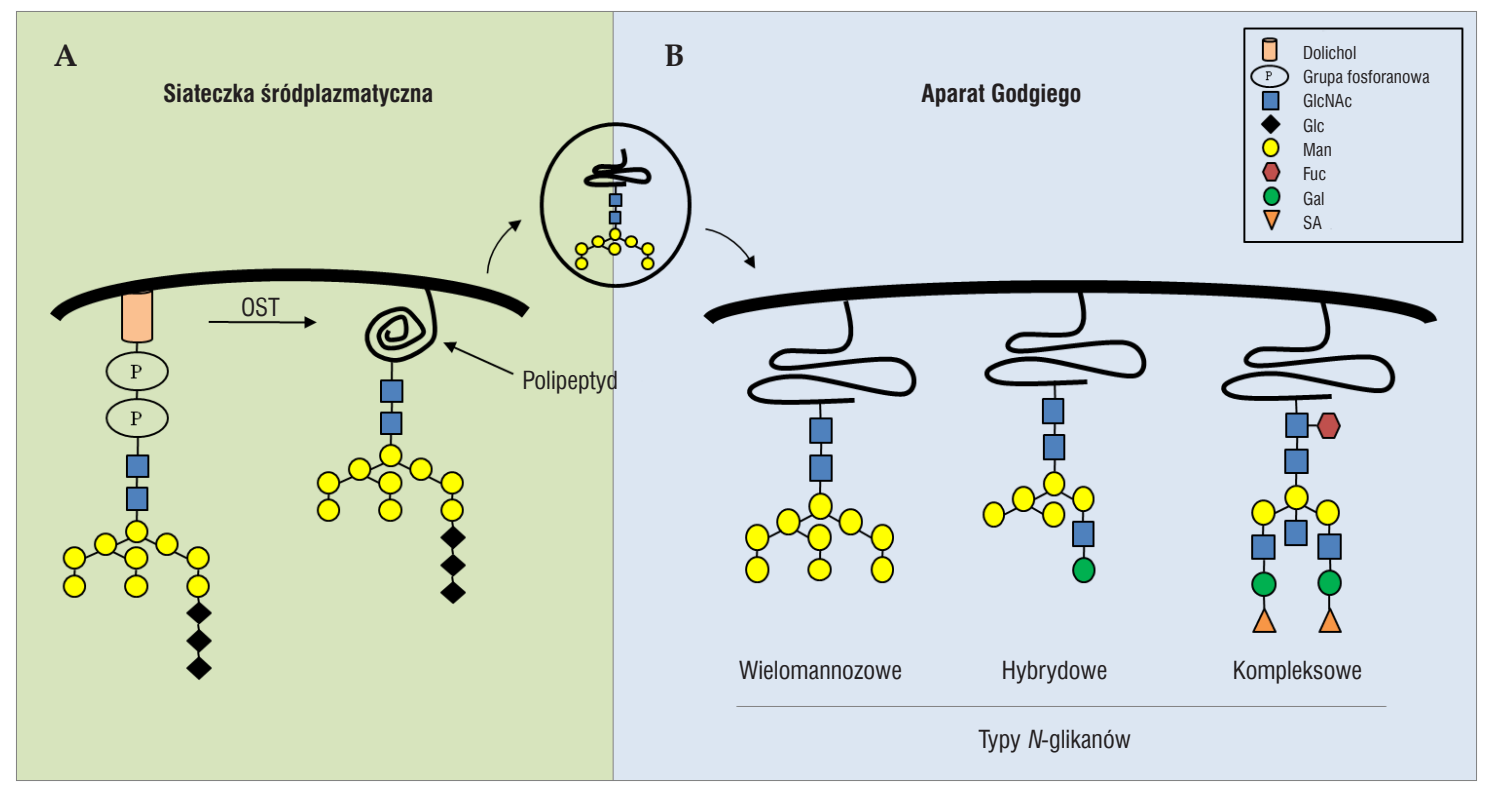

Rycina 1. Uproszczony schemat syntezy N-oligosacharydów. A. Tetradekasacharydowy prekursor $\left(\mathrm{Glc}_{3} \mathrm{Man}_{9} \mathrm{GlcNAc}_{2}\right)$ jest przyłaczony do fosforanu dolicholu, a następnie w siateczce śródplazmatycznej przenoszony jest en bloc na powstajace białko przez oligosacharylotransferaze (OST). B. Po przeniesieniu do aparatu Golgiego, w wyniku obróbki N-oligosacharydu, powstają główne typy N-glikanów: wielomannozowe/oligomannozowe, hybrydowe i kompleksowe/złożone. Fuc — fukoza; Gal — galaktoza; Glc — glukoza; GlcNAc - N-acetyloglukozamina; Man — mannoza; SA — kwas sjalowy

N-oligosacharydy posiadają pentasacharydowy rdzeń zbudowany z dwóch reszt GlcNAc oraz trzech mannoz $\left(\mathrm{GlcNAc}_{2} \mathrm{Man}_{3}\right)[6,7]$.

W zależności od składu łańcuchów bocznych dołączonych do rdzenia wyróżnia się trzy główne klasy struktur N-glikanów: wielomannozowe/oligomannozowe, kompleksowe/złożone i hybrydowe. Glikany wielomannozowe są najstarszymi ewolucyjnie jednostkami, które w zewnętrznej części zawierają od 5 do 9 Man. Oligosacharydy typu kompleksowego, w przeciwieństwie do struktur wielomannozowych, w części zewnętrznej zbudowane są z reszt GlcNAc i galaktozy (Gal), ale nie z Man. Zawierają również fukozę (Fuc) i terminalnie zlokalizowany kwas sjalowy (SA). Oligosacharydy typu hybrydowego są formami pośrednimi między strukturami oligomannozowymi i złożonymi, ponieważ zawierają zarówno łańcuch mannozowy, jak i anteny typu kompleksowego. Synteza oligosacharydów oraz ich dołączanie do białek zachodzi w siateczce śródplazmatycznej (ER, endoplasmic reticulum) oraz aparacie Golgiego (ryc. 1) [8-10].

Stopień $N$-glikozylacji białka zależy od aktywności enzymów, dostępności prekursorów i nukleotydowych donorów cukrów, które w większości powstają w cytoplazmie z urydynodifosforanu (UDP, uridine diphosphate) oraz guanozynodifosforanu (GDP, guanosine diphosphate) [11]. Synteza $N$-glikanów składa się z czterech etapów: syntezy prekursora oligosacharydu związanego z lipidowym nośnikiem (fosforanem dolicholu), przeniesienia łańcucha cukrowego na białko oraz obróbki i wydłużania łańcuchów $N$-oligosacharydów. Prekursorem wszystkich struktur $N$-glikanów jest utworzony wewnątrz ER tetradekasacharyd $\left(\mathrm{Glc}_{3} \mathrm{Man}_{9} \mathrm{GlNAC}_{2}\right)$ przyłączony do dolicholu. Prekursor ten jest następnie przenoszony en bloc z reszty dolicholu na Asn w powstającym polipeptydzie przez enzym oligosacharylotransferazę (OST, oligosaccharyltransferase) (ryc. 1A). Po przeniesieniu na białko wszystkie trzy reszty glukozy (Glc, glucose) są usuwane przez glukozydazy i w efekcie powstaje struktura wielomannozowa $\left(\mathrm{Man}_{9} \mathrm{GlcNAc}_{2}\right)$ $[12,13]$. Na tym etapie $\mathrm{w}$ tworzeniu przestrzennej struktury białka uczestniczą dwie endogenne lektyny: kalneksyna (CNX, calnexin) i kalretikulina (CRT, calreticulin). Działają one jako opiekuńcze cząsteczki i mają zdolność wiązania się z powstającym białkiem przez resztę Glc w N-glikanie $\mathrm{Glc}_{1} \mathrm{Man}_{9} \mathrm{GlcNAc}_{2}$ przyłączonym do białka. Obecność takiej struktury na polipeptydzie wskazuje na jego niepełną lub nieprawidłową konformację. Połączenie CNX/CRT z Glc prowadzi do zmniejszenia agregacji glikoprotein i zwiększenia wydajności fałdowania. Usunięcie terminalnej Glc $\mathrm{w}$ prekursorowym oligosacharydzie jest sygnałem do uwolnienia białka o prawidłowej konformacji z ER [14-16]. Po zakończeniu syntezy N-glikozylowane białko transportowane jest do aparatu Golgiego, gdzie $\mathrm{N}$-oligosacharydy mogą podlegać dalszym modyfikacjom. Enzymy znajdujące się w cysternach aparatu Golgiego przebudowują struktury oligomannozowe, aż do utworzenia ostatecznego $\mathrm{N}$-glikanu (ryc. 1B). Zależna od typu komórki ekspresja glikoenzymów od- 
grywa najważniejszą rolę w określaniu stopnia i rodzaju glikozylacji białka oraz prowadzi do powstawania różnych glikoform (wariantów glikozylacji) białka [17, 18].

\section{Receptor hormonu tyreotropowego (TSHR)}

Receptor hormonu tyreotropowego jest członkiem podrodziny receptorów hormonów glikoproteinowych (GPHR, glycoprotein hormone receptor), należącej do rodziny receptorów sprzężonych z białkiem $\mathrm{G}$, zawierających powtórzenia bogate w leucynę (LGR). Rodzina ta obejmuje także receptory hormonu folikulotropowego (FSH, follicle-stimulating hormone), luteinizującego (LH, luteinising hormone) i ludzkiej gonadotropiny kosmówkowej (hCG, human chorionic gonadotropin) [19, 20]. Gen kodujący TSHR znajdujący się na chromosomie 14q31.1, składa się z 190778 par zasad i 10 egzonów [21]. Na podstawie sekwencji cDNA długość TSHR oszacowano na 764 aminokwasów. Masa cząsteczkowa TSHR wynosi około 84,5 kDa [22]. Oprócz komórek tarczycy TSHR ulega ekspresji także w limfocytach, tkance tłuszczowej i mózgu [23].

\section{Struktura TSHR}

Receptor hormonu tyreotropowego jest typowym receptorem sprzężonym z białkiem $\mathrm{G}$ zbudowanym z 7 transbłonowych, hydrofobowych domen. N-końcowy odcinek receptora skierowany jest na zewnątrz komórki. Zewnątrzkomórkowa domena (ektodomena) liczy połowę masy cząsteczkowej TSHR i zawiera miejsce wiążące TSH, które posiada 9 motywów bogatych w leucynę (LRR, leucine-rich regions). C-końcowa część receptora, zlokalizowana po stronie cytoplazmatycznej, odpowiada za oddziaływanie z białkami G [24, 25]. W przeciwieństwie do pozostałych członków rodziny LGR, TSHR podlega wielu potranslacyjnym modyfikacjom, co prawdopodobnie decyduje o udziale receptora TSH w procesie autoimmunizacyjnym w chorobie Gravesa-Basedowa [22]. Ektodomena TSHR jest cięta proteolitycznie, co prowadzi do powstania podjednostek: dużej A i małej B. Podjednostki te są połączone wiązaniami dwusiarczkowymi. Wyznaczono dwa podstawowe miejsca hydrolizy wiązania peptydowego zachodzącej w trakcie obróbki potranslacyjnej TSHR. Pierwsze N-końcowe miejsce znajduje się pomiędzy 304. a 316. aminokwasem, a drugie C-końcowe jest umieszczone w sekwencji aminokwasowej 366-369. Podjednostka B składa się z domeny transbłonowej siedmiokrotnie przechodzącej przez błonę komórkową, części wewnątrzkomórkowej i fragmentu karboksylowego. Podjednostka A jest główną częścią ektodomeny. Peptyd C łączy podjednostki A i B (ryc. 2). Proteolityczne cięcie jest katalizowane przez metaloproteinazy lub enzymy podobne do konwertazy czynnika martwicy nowotworu [26, 27]. Sugeruje się, że enzymy odpowiedzialne za cięcie mogą należeć też do rodziny adamalizyn (ADAM, a disintegrin and metalloproteinases). Białka ADAM (zawierające domenę dezintegryny

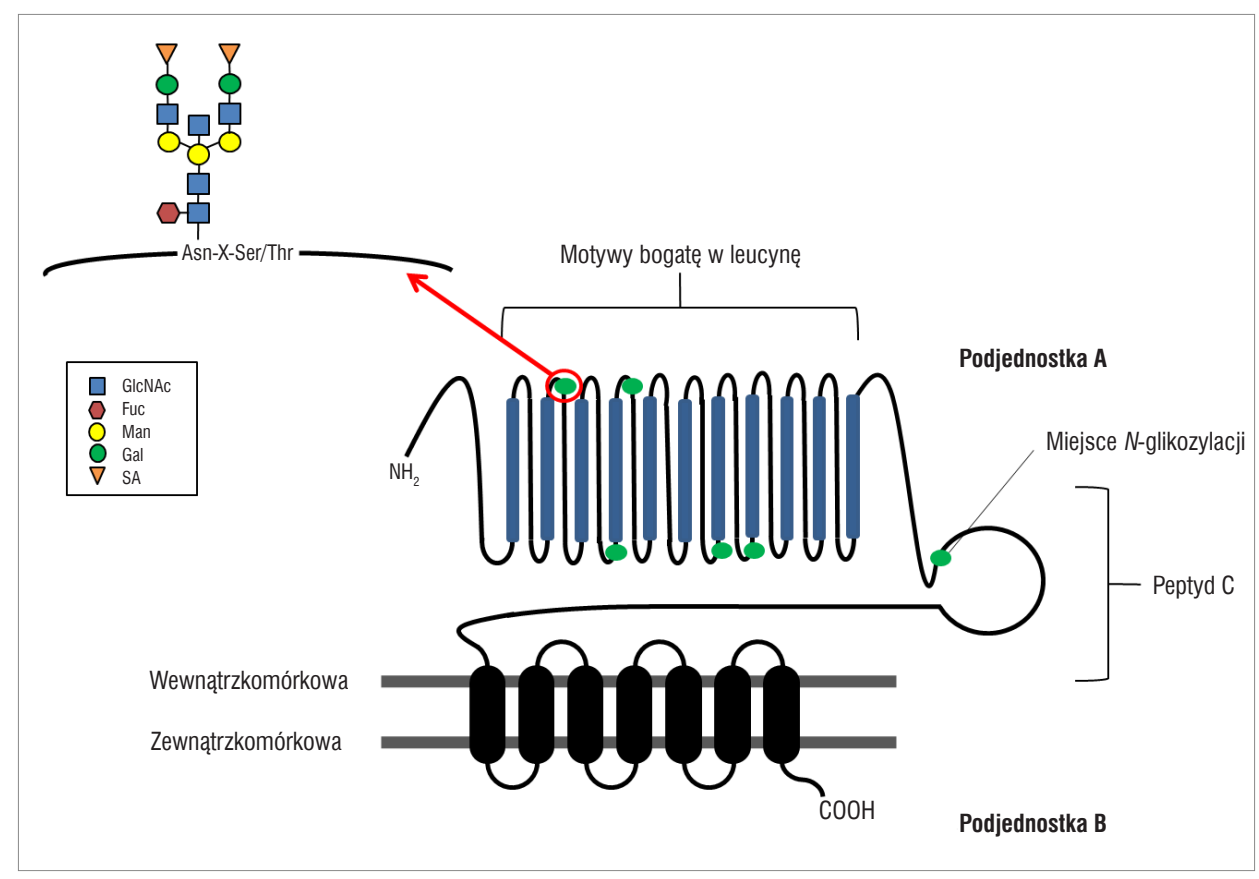

Rycina 2. Struktura TSHR z zaznaczonymi potencjalnymi miejscami N-glikozylacji. Asn — asparagina; Fuc — fukoza; Gal — galaktoza; Glc — glukoza; GlcNAc — N-acetyloglukozamina; Man — mannoza; SA — kwas sjalowy; Ser — seryna; Thr — treonina; X — dowolny aminokwas oprócz proliny 
i metaloproteinazy) są związane z błoną komórkową i odgrywają rolę $\mathrm{w}$ różnych procesach biologicznych, w tym w wydzielaniu cytokin i czynników wzrostu, interakcjach między komórkami i fuzją błon komórkowych. Zarówno przecięte, jak i nieprzecięte formy TSHR występują na powierzchni komórek, jednak w różnych proporcjach. Przewaga jednej z tych postaci może być regulowana przez TSH, interakcje międzykomórkowe lub multimeryzację receptora [28, 29].

\section{Rola TSHR}

Receptor hormonu tyreotropowego odgrywa krytyczną rolę $w$ rozwoju i prawidłowym funkcjonowaniu gruczołu tarczowego. Pojedynczy tyreocyt (komórka pęcherzykowa tarczycy) zawiera około 1000 cząsteczek TSHR na swojej powierzchni. Wiązanie TSH z receptorem prowadzi do zmian w jego konformacji [30]. Powoduje to fosforylację GDP do trifosforanu guanozyny (GTP, guanosine-5'-triphosphate) w podjednostce białka G i jej aktywację. Następnie białko G dysocjuje do aktywnej podjednostki $\mathrm{G} \alpha$-GTP i nieaktywnej $\mathrm{G} \beta \gamma$. Podjednostka G $\alpha$-GTP aktywuje cyklazę adenylową lub fosfolipazę C (PLC, phospholipase C). W kolejnym etapie cyklaza adenylowa aktywuje kinazę białkową A (PKA, protein kinase A) poprzez cykliczny adenozyno- $3^{\prime}, 5^{\prime}$ monofosforan (cAMP, cyclic 3',5'-adenosine monophosphate), podczas gdy PLC rozkłada fosfatydyloinozytol (IP, phosphatidylinositol) do diacyloglicerolu (DAG, diacylglycerol) i trifosforanu inozytolu ( $\mathrm{IP}_{3}$, inositol trisphosphate). Diacyloglicerol aktywuje kinazę białkową $\mathrm{C}$, a $\mathrm{IP}_{3}$ uwalnia jony $\mathrm{Ca}^{2+} \mathrm{z}$ siateczki śródplazmatycznej $[31,32]$. Kinazy białkowe uruchamiają kolejne mechanizmy sygnalizacyjne, które ostatecznie stymulują wiele procesów związanych z syntezą i uwalnianiem hormonów tarczycy, głównie wychwyt jodu, produkcję nadtlenku wodoru, zwiększoną syntezę tyreoperoksydazy (TPO, thyroperoxidase) [33, 34]. Wiązanie TSH $\mathrm{z}$ jego receptorem stymuluje produkcję i uwalnianie hormonów tarczycy: trijodotyroniny $\left(\mathrm{T}_{3}\right)$ i tyroksyny $\left(\mathrm{T}_{4}\right)$. Hormony tarczycy mają plejotropowe działanie. Kontrola metabolizmu poprzez zwiększoną produkcję energii jest najważniejszym zadaniem regulacji hormonalnej tarczycy. Hormony $\mathrm{T}_{3} \mathrm{i} \mathrm{T}_{4}$ regulują zużycie tlenu, aktywują enzymy łańcucha oddechowego, a także zwiększają liczbę i rozmiar mitochondriów [24].

Receptor hormonu tyreotropowego może indukować różne efekty w zależności od tkanki, w której ulega ekspresji. W wysepkach trzustkowych u gryzoni wiązanie TSH z receptorem stymuluje aktywność promotora transportera glukozy 2 (GLUT2, glucose transporter 2) [35]. Hepatocyty bez ekspresji TSHR wykazują zaburzenia wątrobowego metabolizmu lipidów. U myszy z nokautem TSHR specyficznym dla wątroby stężenie cholesterolu przenoszonego przez lipoproteiny o ni- skiej gęstości (LDL, low density lipoprotein) w wątrobie i surowicy jest niższe [36]. Aktywacja TSHR uczestniczy w różnicowaniu mezenchymalnych komórek macierzystych w białą i brunatną tkankę tłuszczową [37]. Wyniki ostatnich badań przeprowadzonych przez Liu i wsp. wskazują, że TSHR bierze również udział w rozwoju nowotworów tarczycy. W badaniu wykazano, że brak TSHR sprzyja tworzeniu przerzutów u pacjentów ze zróżnicowanymi rakami tarczycy (DTC, differentiated thyroid cancer), co skutkuje gorszym rokowaniem. Natomiast ekspresja TSHR obniża inwazję komórek nowotworowych poprzez hamowanie przejścia nabłonkowo-mezenchymalnego (EMT, epithelial-mesenchymal transition) komórek DTC [38].

Receptor hormonu tyreotropowego jest głównym autoantygenem w chorobie Gravesa-Basedowa (GD), jednej z najczęstszych chorób autoimmunizacyjnych tarczycy (AITD, autoimmune thyroid diseases). Przyczyną rozwoju AITD jest przełamanie tolerancji immunologicznej w stosunku do TSHR i zwiększona aktywność tarczycy. Utrata autotolerancji powoduje produkcję autoprzeciwciał skierowanych przeciwko TSHR (TRAb) [39]. W zależności od wpływu autoprzeciwciał na aktywność tarczycy rozróżnia się dwa rodzaje TRAb. Jedne z nich działają jak agoniści TSH i stymulują aktywność TSHR, zwiększając syntezę hormonów tarczycy, co prowadzi do nadczynności gruczołu. Stymulujące TRAb są obecne u większości pacjentów z GD. Drugie TRAb, nazywane przeciwciałami blokującymi, występują rzadziej i hamują aktywację receptora [40]. Co ważne, głównym autoantygenem, który wiąże się ze stymulującymi TRAb, nie jest receptor TSH, ale jego uwalniana podjednostka A. Chociaż GD jest częstą chorobą autoimmunizacyjną tarczycy i dotyka około $1 \%$ populacji, określenie stężenia TRAb w surowicy pacjenta jest trudne przy użyciu konwencjonalnych metod diagnostycznych, takich jak test immunoenzymatyczny (ELISA, enzyme-linked immunosorbent assay) lub Western blotting. Pomiar hamowania wiązania TSH z TSHR jest jedną z metod wykrywania TRAb [41].

Odpowiedź immunologiczna przeciwko TSHR może również prowadzić do rozwoju orbitopatii tarczycowej (TAO, thyroid-associated orbitopathy), określanej również jako oftalmopatia. Orbitopatia tarczycowa jest najczęściej wynikiem reakcji autoimmunologicznych występujących w przestrzeniach poza gałkami ocznymi. W miejscach tych akumulowane są makrofagi, limfocyty T i B, a także kolagen i glikozoaminoglikany, co powoduje akumulację wody. W efekcie dochodzi do obrzęku i powiększenia mięśni okulomotorycznych. Orbitopatia tarczycowa jest częstym objawem GD i nazywa się ją oftalmopatią Gravesa. Zarówno TSHR, jak i TRAb, są prawdopodobnie czynnikami wyzwalającymi proces zapalny w oczodołach [42, 43]. 
Przyczyn rozwoju procesów autoimmunizacyjnych $\mathrm{w}$ gruczole tarczowym dotychczas $\mathrm{w}$ pełni nie poznano, wiadomo jednak, że istotne są zarówno czynniki genetyczne, jak i środowiskowe [44]. Janegova i współpracownicy wykazali, że infekcja wirusem Epsteina-Barra (EBV, Epstein-Barr virus) odgrywa potencjalną rolę w rozwoju AITD. Spośród 34 pacjentów z AITD przebadanych pod kątem obecności EBV w komórkach tarczycy ekspresję wirusowego RNA wykazano w $62,5 \%$ próbkach pobranych od chorych z GD. Obecność EBV stwierdzono głównie w jądrze komórek pęcherzykowych tarczycy [45]. Wykazano, że obecna $w$ krwioobiegu podjednostka A TSHR może odgrywać rolę $w$ inicjacji odpowiedzi immunologicznej. Uwalnianie podjednostki A jest głównie wynikiem przerwania mostków dwusiarczkowych pomiędzy podjednostką A i B przez disulfidoizomerazę białek. Molekularna mimikra również może przyczynić się do rozwoju GD. Obecność bakteryjnych i wirusowych patogenów o strukturze podobnej do ludzkiego TSHR prowadzi do produkcji autoprzeciwciał skierowanych również przeciwko temu receptorowi i powoduje zaburzenia autotolerancji [23].

\section{Glikozylacja TSHR}

Glikozylacja jest jedną z potranslacyjnych modyfikacji TSHR. N-oligosacharydy, przyłączone do TSHR głównie $\mathrm{w}$ regionie ektodomeny (ryc. 2), stanowią prawie jedną trzecią tej glikoproteiny $[5,46]$. We wczesnych badaniach oligosacharydów związanych z TSHR wykazano, że dojrzała, całkowicie glikozylowana postać ludzkiego rekombinowanego receptora w linii komórek jajnika chomika chińskiego (CHO-K1) zawiera GlcNAc przedzielający wiązany $\beta(1,4)$ do trójmannozowego rdzenia $N$-glikanów, rdzeniową Fuc wiązaną $\alpha(1,6)$ do wewnętrznej reszty GlcNAc, Fuc wiązaną $\alpha(1,3)$ do N-acetylolaktozaminy (LacNAc) anten $\mathrm{N}$-glikanów oraz wiązaną $\alpha(1,3)$ Man. Stosując lektynę izolowaną z Maackia amurensis (MAL II), stwierdzono, że w pełni glikozylowany receptor tyreotropiny jest również $\alpha(2,3)$-sjalilowany. Oprócz dojrzałej formy TSHR o masie cząsteczkowej $120 \mathrm{kDa} \mathrm{w}$ analizie białek lizatów CHO-K1, wykonanej metodą Western blotingu, wykrywalny był także niżej położny prążek o masie $100 \mathrm{kDa}$, odpowiadający prekursorowi TSHR. Forma prekursorowa zawierała $\mathrm{N}$-glikany oligomannozowe rozpoznawane przez konkanawalinę A (Con A, Concanavalin $A$ ), swoistą dla $\alpha$ wiązanej Man i przez lektynę izolowaną z Galanthus nivalis (GNL), specyficzną dla Man wiązanej $\alpha(1,3)$ [47]. Podczas obróbki w aparacie Golgiego wielomannozowe N-glikany są przekształcane w oligosacharydy typu kompleksowego, które są charakterystyczne dla dojrzałego receptora obecnego w błonie komórkowej. $N$-glikany typu złożonego są niezbędne do transportu TSHR do błony komórkowej [48]. De- $N$-glikozylowany TSHR nie jest obecny na powierzchni komórek tarczycy. Ponadto obecność sjalowanych struktur w cząsteczce TSHR chroni białko przed proteolizą [49].

Zwiększona zawartość kwasów sjalowych w glikanach TSHR koreluje pozytywnie z wiązaniem TSH przez receptor oraz wydłuża czas wbudowania receptora do błony komórkowej. $W$ zależności od rodzaju sjalotransferaz (SIAT, sialyltransferase), które dołączają SA do glikanów w pozycjach końcowych, wykazano różnice w ekspresji TSHR na powierzchni komórki. Kotransfekcja SIAT1 i SIAT8a z TSHR znacznie zwiększała ekspresję receptora na powierzchni komórkowej w linii fibroblastów nerki małpiej COS-7 w porównaniu z transfekcją SIAT4a. Co więcej, kotransfekcja SIAT1 i SIAT8a zwiększyła akumulację cAMP i produkcję $\mathrm{IP}_{3}$ [50].

Receptor hormonu tyreotropowego zawiera w ektodomenie 6 potencjalnych miejsc $N$-glikozylacji w pozycjach: Asn77, Asn99, Asn113, Asn177, Asn198 i Asn302 (ryc. 2). Większość z nich jest ewolucyjnie konserwatywna, a jedynie Asn113 jest unikalnym miejscem glikozylacji dla ludzkiego TSHR [51]. Wykazano, że zastąpienie Asn glutaminą w pozycjach 77 lub 113 przy użyciu ukierunkowanej mutagenezy wpływa na aktywność biologiczną TSHR. Brak N-glikanów przyłączonych do Asn77 i Asn113 spowodował całkowitą utratę syntezy cAMP stymulowanej wiązaniem TSH. De-N-glikozylacja innych miejsc nie miała wpływu na aktywność TSHR. Co więcej, mutacja w Asn77 całkowicie usuwała powinowactwo receptora do TSH, tak jak w przypadku braku wszystkich sześciu N-glikanów, natomiast mutacja Asn113 tylko zmniejszała to powinowactwo [52]. Z tego powodu można stwierdzić, że obecność $N$-glikanów jest pośrednio potrzebna do wiązania TSH z receptorem i może wpływać na wiązanie TRAb w GD. Wyniki badań przeprowadzonych na komórkach owadów (Spodoptera frugiperda) i bakterii (Escherichia coli) produkujących nieglikozylowane lub częściowo glikozylowane TSHR potwierdzają ten wniosek, ponieważ TSHR ulegające ekspresji w obu tych organizmach nie wiązały TRAb i tyreotropiny lub wiązały je z niskim powinowactwem [53-55]. Dołączanie $N$-oligosacharydów do czterech z sześciu miejsc $N$-glikozylacji TSHR jest konieczne do związania odpowiedniej liczby chaperonów lektynowych CNX/CRT, wymaganych do prawidłowego fałdowania receptora w ER. Mutanty TSHR glikozylowane w trzech lub mniejszej liczbie miejsc glikozylacji mogą nie uzyskać prawidłowej konformacji i nie są transportowane do błony komórkowej, lecz pozostają uwięzione w ER [51].

Siffroi-Fernandez i wsp. wykazali, że interakcje między CNX/CRT a glikozylowanym TSHR spowalniają 
degradację receptora i mają pozytywny wpływ na jego stabilizację [56]. Jedna z hipotez zakłada, że obecność sześciu N-glikanów na powierzchni ludzkiego TSHR jest jednym z czynników wpływających na rozwój GD. U ryb istnieją tylko 4 miejsca $N$-glikozylacji w receptorze TSH, a 5 wykazano u kotów, psów i myszy, w przypadku których nigdy nie stwierdzono autoimmunizacji typowej dla choroby GD występującej u ludzi. Z tego powodu jedna $z$ hipotez zakłada, że intensywniejsza $N$-glikozylacja TSHR u ludzi, wynikająca z obecności 6 motywów Asn-X-Ser/Thr w sekwencji aminokwasowej, może korelować ze stopniem immunogenności receptora i mieć wpływ na utratę tolerancji immunologicznej $[57,58]$.

$\mathrm{W}$ pierwszym etapie procesu autoimmunizacji w AITD antygeny tarczycy są wychwytywane, internalizowane i przetwarzane przez komórki prezentujące antygen (APC, antigen-presenting cell), takie jak makrofagi i komórki dendrytyczne. Komórki te prezentują swoiste antygeny tarczycy limfocytom $\mathrm{T}$ i B, co prowadzi do ich aktywacji i produkcji autoprzeciwciał [59]. Powierzchniowe glikoproteiny tarczycy są rozpoznawane przez receptory mannozowe (ManR) obecne na powierzchni APC. Receptory ManR to zależne od wapnia białka transbłonowe o właściwościach fagocytarnych i endocytarnych. Zawierają one domeny typu $\mathrm{C}$ rozpoznające węglowodany (CRD, carbohydrate recognition domain), które działają jak lektyny i mają zdolność wiązania Man, jak również Fuc, GlcNAci reszt siarczanowych w $\mathrm{N}$-glikanach [60-62]. W podjednostce A TSHR o masie cząsteczkowej $60 \mathrm{kDa}$ aż $43 \%$ masy odpowiada $N$-oligosacharydom. Domeny CRD wiążą się zarówno z podjednostką A TSHR, jak i holoreceptorem TSH poprzez N-glikany. Uważa się, że ta interakcja odgrywa ważną rolę w rozwoju GD [61, 63]. Sugerowano również, że podjednostka A uwalniana z powierzchni tyrocytów najprawdopodobniej przenika do węzłów chłonnych tarczycy (nie do krwi), gdzie jest przetwarzana przez APC i w konsekwencji prowadzi do humoralnej odpowiedzi immunologicznej [29]. N-glikany są niezbędne nie tylko do rozpoznawania TSHR przez APC, ale także są zaangażowane $\mathrm{w}$ kolejny etap odpowiedzi immunologicznej. W badaniach przeprowadzonych w latach 90. wykazano, że $N$-oligosacharydy podjednostki A TSHR są zaangażowane $\mathrm{w}$ wiązanie autoprzeciwciał z receptorem [64].

Chorobom autoimmunizacyjnym towarzyszą zmiany glikozylacji przeciwciał (immunoglobulin — Ig). Autoprzeciwciała TSHR należą głównie do Ig klasy G (IgG) składających się z fragmentów Fab, które wiążą antygen i fragmentów Fc odpowiedzialnych za funkcje efektorowe. Do fragmentów Fc IgG dołączone są dwa $N$-glikany w pozycji Asn297. Kompletne dwuantenowe struktury IgG typu złożonego zawierają
Man, Gal, GlcNAc, Fuc, a także mogą być $\alpha(2,3)-$ lub $\alpha(2,6)$-sjalowane [10, 41, 65]. Łańcuchy cukrowe IgG wpływają na strukturę przeciwciał poprzez stabilizację konformacji i geometrii cząsteczki oraz zwiększają odporność na aktywność proteaz. $N$-glikany regulują uwalnianie IgG przez limfocyty B, ich prawidłowe funkcjonowanie i wiązanie IgG z innymi białkami. Zmiany w glikozylacji IgG są dobrze udokumentowane w niektórych chorobach autoimmunizacyjnych (dotyczy to głównie agalaktozylacji w reumatoidalnym zapaleniu stawów) [10, 66]. Zmiana struktury glikanu prowadzi do nieprawidłowości w wiązaniu IgG z układem dopełniacza, co skutkuje niekontrolowaną jego aktywacją i rozwojem zapalenia [67, 68]. Dotychczas glikozylację IgG w AITD badano w ograniczonym zakresie. Zmiany glikozylacji obserwowano w IgG skierowanych przeciwko tyreoglobulinie (TgAb, thyroglobulin) u pacjentów z GD oraz z zapaleniem tarczycy typu Hashimoto (HT, Hashimoto's thyroiditis), innym bardzo częstym schorzeniem należącym do AITD. Przeciwciała przeciw tyreoglobulinie są obecne w surowicy większości chorych z HT (do 90\%) i u wielu pacjentów z GD (do 40\%) [69]. Wykazano, że TgAb obecne w krwi chorych z HT charakteryzują się słabszą fukozylacją rdzenia niż u pacjentów z GD i u chorych z rakiem brodawkowatym tarczycy [70], podczas gdy poziom $\alpha(1,6)$-fukozylacji i sjalilacji u pacjentów z HT był podwyższony w porównaniu ze zdrowymi dawcami. Ponadto, zaobserwowano dodatnią korelację między glikozylacją IgG a stężeniem TgAb we krwi pacjentów z HT [71]. W ostatnich badaniach $\mathrm{w}$ trzech dużych europejskich kohortach również wykazano zmienioną $\alpha(1,6)$-fukozylację IgG u pacjentów z AITD [72]. Dotychczas nie przeprowadzono żadnych badań $\mathrm{w}$ celu ustalenia, czy glikozylacja TRAb ulega zmianie w GD. Głównym powodem jest zbyt niskie stężenie IgG przeciwko antygenom tarczycy (w tym TRAb) w surowicy osób zdrowych (grupa kontrolna), uniemożliwiające izolację przeciwciał w ilości koniecznej do przeprowadzenia analizy porównawczej struktury $\mathrm{N}$-glikanów, którą standardowo dla IgG wykonuje się metodą wysokosprawnej chromatografii cieczowej (HPLC, high-performance liquid chromatography) [72].

\section{Wnioski}

$\mathrm{N}$-glikozylacja jest kluczowym procesem regulującym strukturę i funkcję receptora TSH [74]. N-glikany są niezbędne dla prawidłowego fałdowania białka TSHR, wbudowywania receptora do błony komórkowej, jak również wiązania TSH i przeciwciał TRAb obecnych w chorobach autoimmunizacyjnych tarczycy [48]. Powszechnie wiadomo, że glikozylacja odgrywa istotną rolę w progresji guza, przerzutach i modulacji immuno- 
logicznej różnych typów nowotworów, w tym guzów tarczycy [3, 73]. Udział zmian glikozylacji w postępie choroby wykazano również w procesach autoimmunizacyjnych [66], między innymi w gruczole tarczowym $[72,75]$. Postawiono hipotezę, zgodnie z którą glikany
TSHR biorą udział w przełamywaniu stanu tolerancji w GD [57]. Do weryfikacji tej hipotezy i lepszego zrozumienia patologicznego mechanizmu autoimmunizacji tarczycy konieczne jest dokonanie szczegółowej analizy zmian glikozylacji TSHR w AITD. 